\title{
BIODIVERSITY OF EDAPHIC FAUNA IN GRAY FOREST SOILS OF THE REPUBLIC OF MOLDOVA
}

\author{
Irina Senicovscaia ${ }^{1, *}$, Andrei Danilov ${ }^{1}$, Andriana Danilov ${ }^{1}$ \\ 1"Nicolae Dimo" Institute of Pedology, Agrochemistry and Soil Protection Chisinau, Republic of Moldova
}

Current Trends in

Natural Sciences

\begin{abstract}
Gray forest soils of the natural ecosystems in the central and northern zones of the Republic of Moldova are the habitat and the source of conservation and reproduction of the edaphic fauna. They represent themselves the standards of the biodiversity for soil invertebrates. Invertebrates sampling was carried out from test cuts by manual sampling of soil layers to the depth of soil fauna occurrence. The main content of invertebrates in gray soils under the forest was in the layer of 0-20 cm. In addition to the Lumbricidae family there were found the species of the Clubionidae, Hydromiidae, Scarabaeidae, Oniscidae, Tortricidae, Julidae, Curculionidae, Carabidae, Geophilidae, Tenebrionidae, Melandryidae and Formicidae families. Species of Eisenia rosea, Euomphalia strigella, Formica rufa, Tortrix viridana, Curculio glandium, Melolontha melolontha and others have been identified in three subtypes of gray forest soils of natural ecosystems. The long use of these soils in agricultural production led to the considerable decrease in the number and biomass of invertebrates and degradation of the faunal complex in general. The number of families decreased from 6-12 to 1-3. Species of Lumbricidae, Elateridae, Tortricidae and Coccinellidae have been found in arable gray forest soils. The trophic pyramids are stable in the typical virgin gray soil. The relationship between trophic levels of the edaphic fauna in the typical gray forest soil is stronger in comparison with albic and molic gray forest soils.
\end{abstract}

Keywords: biodiversity, edaphic fauna, gray forest soil.

\section{INTRODUCTION}

The Republic of Moldova is characterized by a relatively small share of natural landscapes. Agricultural and urban ecosystems comprise almost $85 \%$ of Moldova's territory, while natural and semi-natural ecosystems - about $15 \%$. The main natural ecosystems of the country are the forest (11.2\%) (Republic of Moldova. The Sixth National Report on Biological Diversity, 2019). Intensive human activity leads to disturbance of the ecological balance, fragmentation of natural habitat, intensification of the processes of destruction of ecosystems and degradation of soils. The soil cover of the Republic of Moldova is a subject of desertification and anthropogenic degradation. Dehumification, destructuring and compaction of soils as a result of their long-term use in arable have led to a worsening of the soil biota habitat. Biological degradation accompanies these forms of soil damage and, in some cases, even intensifies it.

Gray forest soils are considered as specific. They spread under the forest and represent a biodiversity conservation area. However, the biggest part of them have been plowed and were subject of prolonged agricultural use. 
The study of invertebrates in gray forest soils (at the same time as brown soils) on the territory of Moldova was initiated in 1960 under the leadership of professors Gilyarov M.S. and Krupenikov I.A.. The zoological diagnostic research of the gray forest soils was started (Perel, 1962).

In the period 1960-1970 zoofaunistic monitoring of the virgin (under the forest) and arable gray soils was carried out by N.A. Prohina (Prohina and Marinescu, 1972). During these years, changes in the biogenic state of intensively exploited soils were determined. Researches to assess links between the abundance of mesofauna and productive capacity of main soils have begun.

In the years 2006-2016 the database for some indicators in gray forest soils was created, the results of research on the current state of the biota of gray forest soils on the site in the Ivancea village, Orhei region were generalized (Senicovscaia et al., 2010, 2012; Senicovscaia, 2016).

The conception of the "ecological standard" of a species, proposed by Gilyarov M.S. (1965), about the requirement of each animal species in a certain complex of environmental conditions forms the theoretical base for the application of the data of soil fauna studies to the purpose of the identification of the course of soil formation processes and of their changes under the influence of human activity. Each species within its distribution range can be found in certain habitats, where the environmental conditions correspond to the requirement of this species. The combination of the main environmental factors (temperature, humidity, food etc.), providing the existence of a given species, corresponds to its "ecological standard". The close relations of the edaphic fauna with the habitat allow us to consider that its indicators are one of the characteristics of the state of ecosystems (Бессолицына, 2001). The structure of faunal complexes and the range of its variation in the spatio-temporal aspect can serve as one of the characteristics of geosystems' stability to external influences and the capacity of biotic communities for self-repair.

Invertebrates' diversity is one of the most important evaluation criteria of soil ecosystems, theia resistance to different forms of degradation (Naeem et al., 2002; Schwartz et al., 2000). Pedobionts can serve as a test-objects for indicating degradation processes and for assessing the quality and health of soils.

The purpose of the research was to investigate the biodiversity of edaphic fauna in gray forest soils of natural ecosystems and to determine the effect of the long-term agricultural land utilization on the soil invertebrates' status for the biodiversity conservation and development of the national soil biota quality standards.

\section{MATERIALS AND METHODS}

Our comparative study has been performed in central and northern zones of the Republic of Moldova. The edaphic fauna' content, biomass, biodiversity and profile distributions in gray forest soils with the normal profile in the condition of the long-term use in agricultural production were investigated in comparison with the undisturbed soils in natural ecosystems. Three experimental sites have been tested. Investigations were performed on the molic, albic and typical gray forest soils (classification of soils by Ursu A. $(2001,2016)$.

The site with molic gray forest soil (profile 3 under forest; profile 4 under arable) is situated near the Grozeshti village (Nisporeni region). According to zoning pedogeographic, this site is located in the Central Plateau of Kodru Forests, in the region V of Kodru' Plateau, in the district No. 8 of brown, gray forest soils and leached chernozems.

The site with typical gray forest soil (profile 9 under forest; profile 10 under arable) is also located in the hilly forest steppe zone of the Northern Plain (I), the forest-steppe hill of Rezina district No. 5 of gray forest soils and argillaceous chernozems near the Raspopeni village (Sholdaneshti region). 


\section{Current Trends in Natural Sciences}

Vol. 10, Issue 19, pp. 134-141, 2021

https://doi.org/10.47068/ctns.2021.v10i19.018

Current Trends in Natural Sciences (on-line)

ISSN: 2284-953X

Current Trends in Natural Sciences (CD-Rom)

ISSN: 2284-9521

ISSN-L: 2284-9521

ISSN-L: 2284-9521

The site with albic gray forest soil (profile 7 under forest; profile 8 under arable) falls within the hilly forest-steppe zone of the Northern Plain (I), in the forest-steppe of the Northern Plateau, in the district No. 1 of gray forest soils and clay-alluvial chernozems. Nearby is the Terebna village (Edinets region).

Status of invertebrates. Testing of semi-profiles in the amount of 3 units was carried out around the main test cut at a distance of 5-10 m. The state of invertebrates was determined from test cuts by manual sampling of soil layers to the depth of soil fauna occurrence with application of Gilyarov and Striganova's method (1987). The identification of invertebrate's diversity at the family's level and their classification according to nutrition type were categorised according to Gilyarov and Striganova (1987).

\section{RESULTS AND DISCUSSIONS}

Gray forest soils are characterized by a low content of edaphic fauna (especially from the Lumbricidae family) during the sampling period due to prolonged drought, low humidity and the high compaction of soil horizons. The number and biomass of edaphic fauna in gray forest soils of natural ecosystems are characterized by the higher values of these indicators in comparizon with arable soils (Table 1). The typical gray forest soil contains invertebrates on average $96.0 \mathrm{ex} \mathrm{m}^{-2}$, molic soil - $90.7 \mathrm{ex} \mathrm{m}^{-2}$, albic soil - $40.0 \mathrm{ex} \mathrm{m}^{-2}$ with a biomass of $4.7 ; 10.7$ and $4.1 \mathrm{~g} \mathrm{~m}^{-2}$. Although these values are much lower than those previously recorded on gray forest soils (Senicovscaia et al., 2012; Senicovscaia, 2016).

Soil faunistic studies of gray forest soils in agricultural conditions have demonstrated and have confirmed that the long-term use of arable land leads to a considerable decrease in the number and biomass of invertebrates and to the degradation of the soil faunal complex in general. Number of invertebrates and Lumbricidae fam. in the molic gray forest soil decreases on average from 90.7 to $16.0 \mathrm{ex} \mathrm{m}^{-2}$ and from 29.3 to $5.3 \mathrm{ex} \mathrm{m}^{-2}$ accordingly, and in the albic and typical gray forest soil these indicators decrease to zero values. Similar changes were observed in the biomass of the edaphic fauna.

Table 1. Number and biomass of invertebrates in gray forest soils under forest and arable land $(n=3$ for each profile)

\begin{tabular}{|c|c|c|c|c|c|c|}
\hline \multirow{2}{*}{ Soil } & \multirow{2}{*}{ Land use } & \multirow{2}{*}{ Profile } & \multicolumn{2}{|c|}{ Number, ex m ${ }^{-2}$} & \multicolumn{2}{|c|}{ Biomass, $\mathrm{g} \mathrm{m}^{-2}$} \\
\hline & & & total & Lumbricidae fam. & total & Lumbricidae fam. \\
\hline \multirow{2}{*}{ Molic gray forest soil } & forest & P3 & 90.7 & 29.3 & 10.7 & 8.3 \\
\hline & arable & $\mathrm{P} 4$ & 16.0 & 5.3 & 2.7 & 1.6 \\
\hline \multirow{2}{*}{ Albic gray forest soil } & forest & P7 & 40.0 & 8.0 & 4.1 & 1.1 \\
\hline & arable & P8 & 0 & 0 & 0 & 0 \\
\hline \multirow{2}{*}{ Typical gray forest soil } & forest & P9 & 96.0 & 0 & 4.7 & 0 \\
\hline & arable & $\mathrm{P} 10$ & 2.7 & 0 & 0.1 & 0 \\
\hline
\end{tabular}

The share of earthworms in the total abundance of invertebrates in the molic gray forest soil of natural ecosystems constitutes of $32.3 \%$, in the albic gray forest soil $-20.0 \%$. Their contribution to the total biomass is $77.6 \%$ and $26.8 \%$ accordingly. The average weight of one exemplar of Lumbricidae fam. in the virgin molic gray forest soil constitutes $0.28 \mathrm{~g}$, in the virgin albic gray forest soil $-0.14 \mathrm{~g}$. The typical gray forest soil is characterized by a total lack of earthworms at the time of fauna sampling. Arable albic and typical soils were also devoid of earthworms. The base 


\section{Current Trends in Natural Sciences}

Vol. 10, Issue 19, pp. 134-141, 2021

https://doi.org/10.47068/ctns.2021.v10i19.018

Current Trends in Natural Sciences (on-line)

ISSN: 2284-953X

Current Trends in Natural Sciences (CD-Rom)

ISSN: 2284-9521

ISSN-L: 2284-9521

ISSN-L: 2284-9521

mass of fauna in gray forest soils under the forest is located in the $0-20 \mathrm{~cm}$ layer: in the molic gray soil $-100.0 \%$, in the albic gray soil $-93.3 \%$, in the typical gray soil $-83.3 \%$. The number of invertebrates index decreases in the soil profile to a depth of $30 \mathrm{~cm}$ (Figure 1).
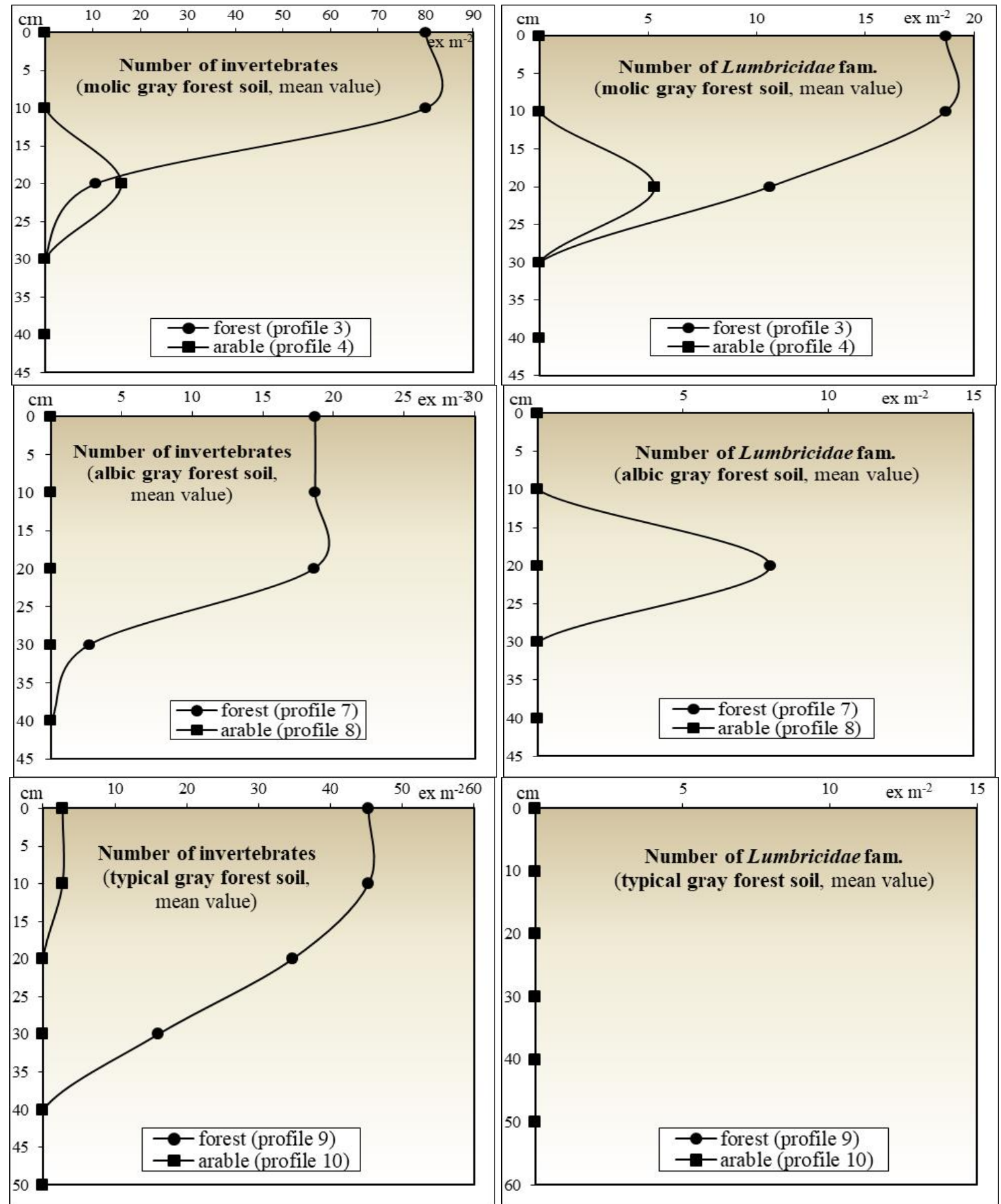

Figure 1. The profile distribution of invertebrates and Lumbricidae family in the gray forest soils in natural and agricultural ecosystems (mean values, $n=3$ for each soil layer) 


\section{Current Trends in Natural Sciences}

Vol. 10, Issue 19, pp. 134-141, 2021

https://doi.org/10.47068/ctns.2021.v10i19.018

Current Trends in Natural Sciences (on-line)

ISSN: 2284-953X

Current Trends in Natural Sciences (CD-Rom)

ISSN: 2284-9521

ISSN-L: 2284-9521

ISSN-L: 2284-9521

Lumbricidae family in the virgin molic gray forest soil is located in the $0-20 \mathrm{~cm}$ layer $(100.0 \%)$, in the virgin albic gray forest soil - in the 10-20 cm layer.

Gray forest soils in the natural ecosistem are characterized by a high diversity of invertebrates compared to arable gray forest soils (Table 2). There are 6 families of invertebrates in the molic gray soil, 7 families - in the albic gray soil and 12 families of edaphic fauna - in the typical gray soil.

Table 2. Biodiversity of invertebrates (ex $\mathrm{m}^{-2}$ ) at the family's level in gray forest soils in natural and agricultural ecosystems (mean values)

\begin{tabular}{|l|c|c|c|c|c|c|}
\hline \multirow{2}{*}{\begin{tabular}{|l} 
Invertebrates' families \\
\cline { 2 - 7 }
\end{tabular}} & \multicolumn{2}{|c|}{ Molic gray forest soil } & \multicolumn{2}{c|}{ Albic gray forest soil } & \multicolumn{2}{c|}{ Typical gray forest soil } \\
\cline { 2 - 7 } & forest (P3) & arable (P4) & forest (P7) & arable (P8) & forest (P9) & $\begin{array}{c}\text { arable } \\
\text { (P10) }\end{array}$ \\
\hline Lumbricidae & 29.3 & 5.3 & 8.0 & 0 & 0 & 0 \\
\hline Elateridae (larvae) & 0 & 2.7 & 0 & 0 & 0 & 0 \\
\hline Julidae & 0 & 0 & 2.7 & 0 & 10.7 & 0 \\
\hline Scarabaeidae (larvae) & 2.7 & 0 & 2.7 & 0 & 2.7 & 0 \\
\hline Curculionidae (larvae) & 0 & 0 & 16.0 & 0 & 5.3 & 0 \\
\hline Carabidae & 0 & 0 & 0 & 0 & 5.3 & 0 \\
\hline Coccinellidae & 0 & 0 & 0 & 0 & 0 & 2.7 \\
\hline Geophilidae & 0 & 0 & 0 & 0 & 8.0 & 0 \\
\hline Tenebrionidae (larvae) & 0 & 0 & 0 & 0 & 26.7 & 0 \\
\hline Clubionidae & 2.7 & 0 & 0 & 0 & 5.3 & 0 \\
\hline Hydromiidae & 37.3 & 0 & 2.6 & 0 & 8.0 & 0 \\
\hline Oniscidae & 10.7 & 0 & 8.0 & 0 & 16.0 & 0 \\
\hline Melandryidae (larvae) & 0 & 0 & 0 & 0 & 2.7 & 0 \\
\hline Tortricidae (larvae) & 8.0 & 2.7 & 0 & 0 & 5.3 & 0 \\
\hline Formicidae & 0 & 0 & + & 0 & +++ & 0 \\
\hline Unidentified species & 0 & 5.3 & 0 & 0 & 0 & 0 \\
\hline \multicolumn{1}{|c|}{ Total } & $\mathbf{9 0 . 7}$ & $\mathbf{1 6 . 0}$ & $\mathbf{4 0 . 0}$ & $\mathbf{0}$ & $\mathbf{9 6 . 0}$ & $\mathbf{2 . 7}$ \\
\hline
\end{tabular}

In addition to the Lumbricidae family the species from the families of Clubionidae, Hydromiidae, Scarabaeidae, Oniscidae and Tortricidae have been found in the virgin molic gray forest soil. Species from the family of Julidae, Scarabaeidae, Curculionidae, Hydromiidae, Oniscidae and Formicidae have been identified in the faunal samples from the virgin albic gray forest soil. The highest number of invertebrates' families was found in the typical gray forest soil: Julidae, Scarabaeidae, Curculionidae, Carabidae, Geophilidae, Tenebrionidae, Clubionidae, Hydromiidae, Oniscidae, Melandryidae, Tortricidae and Formicidae.

In the gray forest soils of natural ecosystems species of Eisenia rosea, Euomphalia strigella, Formica rufa, Coccinella septempunctata, Tortrix viridana, Curculio glandium, Melolontha melolontha and others have been identified.

The biodiversity of pedobionts in arable gray forest soils is significantly reduced. The molic gray forest soil contains 3 families of invertebrates (Lumbricidae, Elateridae and Tortricidae), the typical gray forest soil - 1 family of edaphic fauna (Coccinellidae).

Some of the total number of invertebrates are saprophages. Their amount in the virgin molic gray forest soil is $44.1 \%$, in the virgin albic gray forest soil $-86.8 \%$ and in the virgin typical gray forest soil $-36.2 \%$ from the total abundance of invertebrates (Figure 2). 

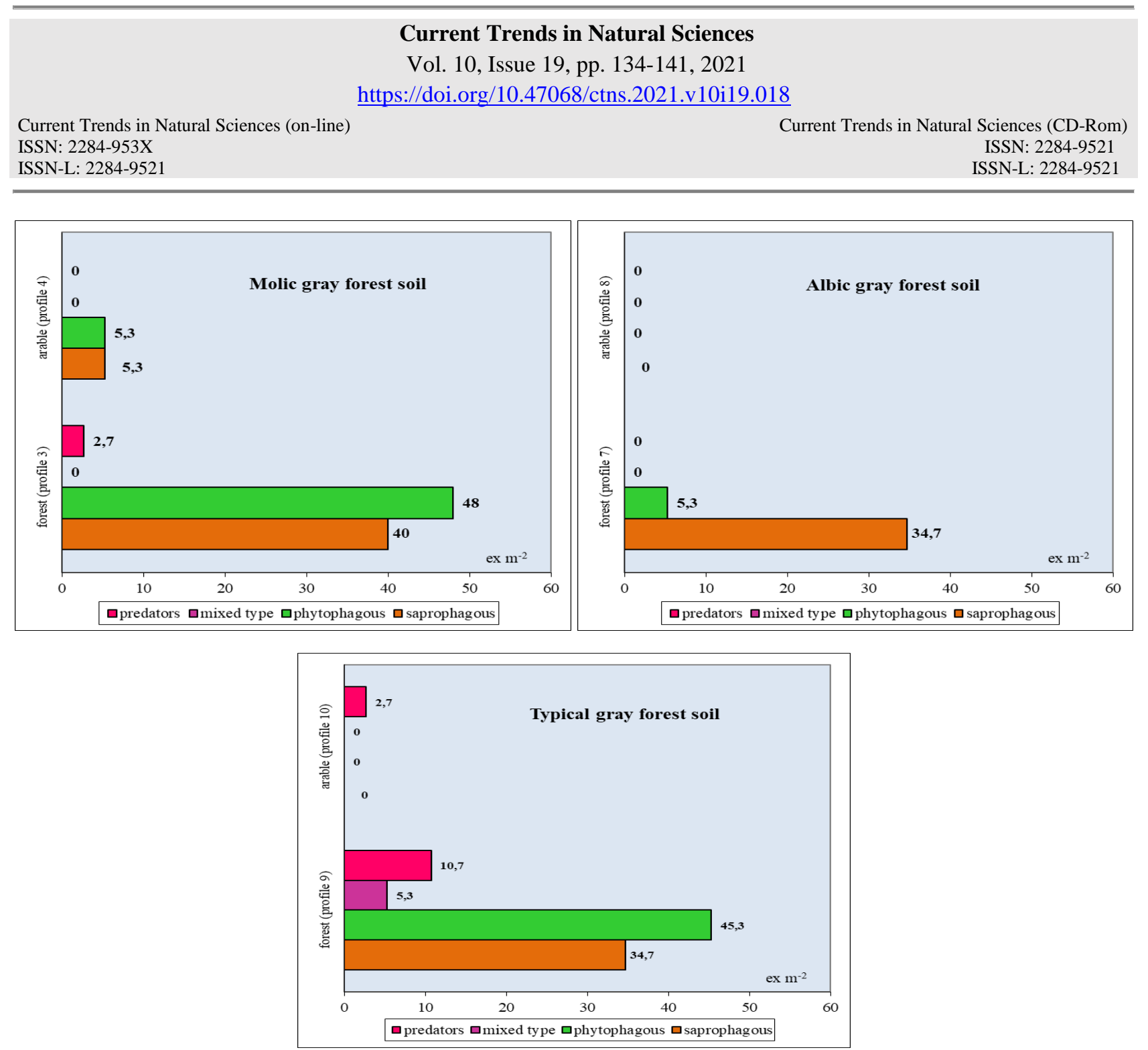

Figure 2. Composition of invertebrates according to the mode of nutrition in gray forest soils of natural and agricultural ecosystems (mean values, without Formicidae fam. and unidentified species)

The share of saprophagous in the total number of invertebrates in agroecosystems is $50.0 \%$ in the molic gray forest soil. Saprophages were absent in arable albic and typical soils at the time of sampling.

Molic and typical gray forest soils under forest are characterized by the higher number of species belonging to the phytophagous group - $52.9 \%$ and $47.2 \%$ respectively.

The number of invertebrates with the mixed type of nutrition and predators in gray forest soils in natural ecosystems was insignificant. The maximum abundance of predators in the amount of $11.1 \%$ were recorded in the typical gray forest soil.

Trophic pyramids are stable in the typical virgin gray soil. The quantitative relations between trophic levels of edaphic fauna in the typical gray forest soil are stronger in comparison to the molic and albic soil (Figure 2, Table 3).

The long-term arable use of gray forest soils leads to the significant deterioration of the conditions needed for the vital activity of soil invertebrates, the rupture and the attenuation of relations between the components of the edaphic fauna which, in turn, contributes to the decrease in the natural stability of soils and the strenghtening of degradation processes. 
Current Trends in Natural Sciences

Vol. 10, Issue 19, pp. 134-141, 2021

https://doi.org/10.47068/ctns.2021.v10i19.018

Current Trends in Natural Sciences (on-line)

Table 3. The ratio of trophic groups of invertebrates in gray forest soils

\begin{tabular}{|c|c|c|c|c|c|}
\hline Soil & Land use & Profile & Saprophagous /Total & Saprophagous / Phytophagous & Phytophagous /Total \\
\hline \multirow{2}{*}{ Molic gray forest soil } & forest & P3 & 0.44 & 0.83 & 0.53 \\
\cline { 2 - 6 } & arable & P4 & 0.5 & 1.00 & 0.5 \\
\hline \multirow{2}{*}{ Albic gray forest soil } & forest & P7 & 0.87 & 6.55 & 0.13 \\
\cline { 2 - 6 } & arable & P8 & 0 & 0 & 0 \\
\hline \multirow{2}{*}{ Typical gray forest soil } & forest & P9 & 0.36 & 0.77 & 0.47 \\
\cline { 2 - 6 } & arable & P10 & 0 & 0 & 0 \\
\hline
\end{tabular}

The decline in the organic matter content, the compaction of arable soils and massive diffusion with excessive application of chemical fertilizers and xenobiotic compounds in the agriculture resulted in the fragmentation and simplification of soil habitats. Research results have demonstrated that the balance between invertebrate populations is disturbed, which over time leads to a decrease in the quality and fertility of arable gray forest soils.

\section{CONCLUSIONS}

Gray forest soils of the natural ecosystems in the central and northern zones of the Republic of Moldova are the habitat and the source of conservation and reproduction of the edaphic fauna. They represent themselves the standards of the biodiversity for soil invertebrates. The edaphic fauna composition in natural ecosystems is complex and diverse. 6-12 families of invertebrates were found in virgin gray forest soils.

The main content of invertebrates in gray soils under the forest was in the layer of $0-20 \mathrm{~cm}$. Indicators of the edaphic fauna in soil profiles have been decreased with the depth.

Saprophagous prevail in the composition of the edaphic fauna in the virgin gray soil under forest, accounting for $44.1 \%$ of the total abundance in the molic gray forest soil, $86.8 \%$ in the albic gray forest soil and $36.2 \%$ in the typical gray forest soil respectively.

Trophic pyramids are stable in the typical virgin gray soil. Links between trophic levels of edaphic fauna in the typical gray forest soil are stronger in comparison to the molic and albic gray soil.

The current state of the edaphic fauna in arable gray forest soils is characterized by a considerable decrease in the abundance, biomass and biodiversity compared to those of virgin soils. The number and biomass of invertebrates in arable gray forest soils are lower by 5.7-35.6 times and by 4.0-47.0 times compared to soils-standards of the biodiversity. In arable soils only species from 1-3 families of edaphic fauna have been identified. There is a decrease in the number of saprophagous, especially in the Lumbricidae family, the destruction of levels and trophic links between invertebrates.

The negative effect on the edaphic fauna is observed as a result of long-term land management practices without organic fertilizers. A land management with the fallow areas and natural migration corridors is recommended for regeneration of soil invertebrates and natural restoration of the quality of gray forest soils.

\section{ACKNOWLEDGEMENTS}

This research work was carried out in the framework of the institutional project "Evaluation of the soil state of the Republic of Moldova in the agrocenosis conditions, improvement of the classifier and the soil rating 


\section{Current Trends in Natural Sciences}

Vol. 10, Issue 19, pp. 134-141, 2021

https://doi.org/10.47068/ctns.2021.v10i19.018

Current Trends in Natural Sciences (on-line)

system, elaboration of the methodological-informational framework for monitoring and enlarged fertility reproduction" (project code 20.80009.7007.17) in 2020.

\section{REFERENCES}

Bessolitsyna E.P. (2001). Landscape-ecological analysis of the structure of zoocenoses of soils in southern Siberia [Бессолицына Е. П. Ландшафтно-экологический анализ структуры зооценозов почв юга Сибири]. Irkutsk: FUE «Publishing House SB RAS».

Gilyarov, M.S., Striganova, B.R. (Ed.). (1987). Quantitative Methods in Soil Zoology. [Гиляров М.С., Стриганова Б.Р. (Ред.). Количественные методы в почвенной зоологии]. Moscow, USSR: Nauka.

Lozan Angela, Veronica Josu, Charles Gbedemah, Ion Cotofană (2019). The Sixth National Report on Biological Diversity. Contribution: Valeriu Caisîn et al.; transl.: Elena Bivol. UN Convention on Biological Diversity, UN Environment/ GEF. Chișinău: S.n., Tipogr. "Bons Offices”.

Naeem, S., Loreau, M., Inchausti, P. (2002). Biodiversity and ecosystem functioning: the emergence of a sysnthetic ecological framework. In Loreau, M., Naeem, S., Inhausti, P., eds., Biodiversity and ecosystem functioning: synthesis and perspectives. (pp. 3-11). Oxford University Press.

Perel T.S. (1962). Some regularities in the distribution of Lumbricidae on the territory of Moldova. [Перель Т.C. Некоторые закономерности в распределении Lumbricidae на территории Молдавии]. Zoological journal [Зоологический журнал], XLI, 8, 1149-1161. Moscow, USSR: Academy of Sciences.

Prohina N.A., Marinescu K.M. (1972). Biological features of chernozems and gray forest soils of Moldova [Прохина Н.А., Маринеску К.М. Биологические особенности черноземов и серых лесных почв Молдавии]. In Biological activity of soils in Moldova [Биологическая активность почв Молдавии ] (pp.- 88-98). Kishinev.

Schwartz, M.W., Brigham, C.A., Hoeksema, J.D., Lyons, K.G., Mills, M.H., van Mantgem, P.J. (2000). Linking biodiversity to ecosystem function: implications for conservation biology. Ecologia, 122, 297-305.

Senicovscaia Irina (2016). Biota's evolution of gray forest soils in the central zone of the Republic of Moldova. Scientific Papers. Series A. Agronomy, Vol. LIX, 136-143, Bucharest. http://agronomyjournal.usamv.ro/pdf/2016/Art23.pdf

Senicovscaia Irina, Calina Marinescu, Serafim Andrieş, Vladimir Filipciuc, Boris Boincean, Ludmila Bulat, Aureliu Burghelea, Tatiana Botezatu, Raisa Daniliuc. (2012). Instrucţiuni metodice privind evaluarea şi sporirea rezistenţei biotei solurilor în condiţiile intensificării proceselor de degradare [Methodical instructions for assessing and increasing the resistance of soil biota in conditions of intensification of degradation processes]. Chișinău: Pontos.

Senicovscaia Irina, Marinescu Calina, Demcenco Elena, Lungu V. (2010). Impactul utilizării la arabil și a îngrășămintelor minerale asupra calității biotei solurilor cenușii din Moldova Centrală [Impact of arable use and mineral fertilizers on the quality of gray soil biota in Central Moldova]. In Cerbari V., eds., Monitoringul calităţii solurilor Republicii Moldova (Baza de date, prognoze, recomandări) (pp. 341-347). Chişinău: Pontos.

State of Knowledge of Soil Biodiversity. Status, challenges and potentialities. Report 2020, Report Soil Biodiversity.pdf Ursu A. (2001). Clasificarea solurilor Republicii Moldova (ediția II). [Soil classification of the Republic of Moldova (second edition)] Chișinău.

Ursu A. (2016). Clasificarea solurilor Republicii Moldova. Argumentări și explicaţii [Soil classification of the Republic of Moldova. Arguments and explanations]. Buletinul AŞM. Ştiinţele vieţii, 2(329), 141-149. 